\title{
Glucocorticoid-induced Alterations in the Sodium Potassium Pump of the Human Erythrocyte
}

\author{
DeepaK M. KajI, UshaKant ThaKKar, and Thomas Kahn, with the technical \\ assistance of JOHN A. TORELLI, Department of Medicine, Veterans Administration \\ Medical Center, Bronx, New York 10468; Mt. Sinai School of Medicine, \\ City University of New York, New York 10029
}

A B S T RACT To evaluate the effects of glucocorticoids on the Na-K pump in human subjects, we evaluated the intracellular sodium and potassium, ${ }^{42} \mathrm{~K}$ in flux across and the $\left[{ }^{3} \mathrm{H}\right]$ ouabain binding to cell membranes of intact human erythrocytes from a group of subjects taking glucocorticoids and a group of normal subjects. Intracellular sodium concentration was lower $(7.2 \pm 0.4 \mathrm{vs} .10 .9 \pm 0.2 \mathrm{mmol} / \mathrm{liter}$ cell water $)$ and intracellular potassium concentration higher $(149.8 \pm 1.5 \mathrm{vs}$. $137.2 \pm 1.2 \mathrm{mmol} /$ liter cell water) in erythrocytes from steroid-treated patients. In spite of a significantly decreased intracellular sodium which normally diminishes ouabain-sensitive ${ }^{42} \mathrm{~K}$ influx, the ouabain-sensitive $\mathrm{K}$ influx was unchanged in erythrocytes from the steroid-treated group. Maximum $\left[{ }^{3} \mathrm{H}\right]$ ouabain binding was markedly higher in the steroid-treated group $(835 \pm 44$ vs. $449 \pm 11$ sites/cell). There was close linear correlation between $\left[{ }^{3} \mathrm{H}\right]$ ouabain binding and inhibition of $K$ pump, suggesting the specificity of ouabain binding to Na-K pump sites on the cell membrane. Association kinetics for ouabain were similar in the two groups despite the marked difference in the amount of $\left[{ }^{3} \mathrm{H}\right]$ ouabain binding. External potassium concentration required for half-maximum ouabain-sensitive $\mathbf{K}$ influx was identical in the two groups. Thus, the additional $\mathrm{Na}-\mathrm{K}$ pump sites in the steroid-treated group were qualitatively similar to those in normals. These results suggest that administration of glucocorticoids leads to an increase in the number of Na-K pump sites. The increase in the number of $\mathrm{Na}-\mathrm{K}$ pump sites may explain the low levels of intracellular sodium and higher cell potassium observed in steroid-treated subjects.

A preliminary report of this work was presented at the Annual Meeting of the American Federation of Clinical Research, May 1980, and appeared in abstract form in 1980. (Clin. Res. 28: 269.)

\section{INTRODUCTION}

A large body of evidence supports the concept that the intracellular concentration of sodium and potassium and the transcellular movement of these monovalent cations are influenced by a specific transport system, consisting of an ATPase and usually referred to as the sodium potassium pump (1-3). Glucocorticoids have been shown to increase Na-K ATPase activity in the rat kidney $(4,5)$ and more recently in the small and large intestine (6). Erythrocytes from two patients with Cushing's syndrome have also been reported to show increased Na-K ATPase activity (7) but the effects of glucocorticoids on the Na-K pump in human subjects have not been extensively investigated.

The present studies were designed to evaluate the influence of glucocorticoids on the Na-K pump of erythrocytes from human subjects. Previous investigators have used $\left[{ }^{3} \mathrm{H}\right]$ ouabain to quantitate the number of $\mathrm{Na}-\mathrm{K}$ pump sites on various cell types in the healthy state $(8-10)$. The use of this radioligand permitted us to quantitate the number of Na-K pump sites on human erythrocytes and to correlate changes in the number of Na-K pump sites with observed alterations in intracellular electrolytes and potassium flux across cell membranes. The human erythrocyte was chosen because of its known contribution to the elucidation of the normal physiology of the Na-K pump and its easy accessibility in human subjects. Our results indicate a consistent and marked alteration in the Na-K pump of human erythrocytes following the administration of glucocorticoid hormones.

\section{METHODS}

\section{Subjects}

Subjects were divided into two categories

Group I. Normal group. This group consisted of 24 heal thy adults, 20 males and 4 females, none of whom was on any 
drugs. Their ages ranged from 29 to $44 \mathrm{yr}$ (mean age, $36 \mathrm{yr}$ ). Group II. Steroid-treated group. This group consisted of 17 patients, 15 males and 2 females. Their ages ranged from 28 to $82 \mathrm{yr}$ (mean age, $48 \mathrm{yr}$ ). Subjects in the steroidtreated group were selected for inclusion in the study if they were receiving $20 \mathrm{mg} / \mathrm{d}$ prednisone (or other glucocorticoids with its equivalent dose) for $4 \mathrm{wk}$ or more and if cardiac glycosides were not administered in the week before the study. Blood transfusion within 8 wk before the study was an indication for exclusion. Six subjects were studied before and during glucocorticoid administration.

\section{Solution and chemicals}

Incubation medium for $\left[{ }^{3} \mathrm{H}\right]$ ouabain binding consisted of a K-free solution containing $130 \mathrm{mM} \mathrm{NaCl}, 10 \mathrm{mM}$ glucose, 10 $\mathrm{mM}$ Tris $\cdot \mathrm{HCl}, 20 \mathrm{mM}$ sucrose, $\mathrm{pH} 7.45$, at $37^{\circ} \mathrm{C}(\mathrm{Na}-\mathrm{T}-\mathrm{G})^{1}$ with $0.1 \mu \mathrm{M}\left[{ }^{3} \mathrm{H}\right]$ ouabain. The effective osmolarity of the solution, measured without glucose and Tris, was $282 \pm 10 \mathrm{mosmol} /$ kg water (Fiske osmometer, Fiske Associates, Inc., Uxbridge, Mass.). Standard incubation medium for ${ }^{42} \mathrm{~K}$ influx consisted of $\mathrm{Na}-\mathrm{T}-\mathrm{G}$ solution with $\mathrm{KCl} 10 \mathrm{mM}$ substituted in equimolar amounts for $\mathrm{NaCl}$.

$\left[{ }^{3} \mathrm{H}\right]$ Ouabain was obtained as dry powder (New England Nuclear, Boston, Mass.) and dissolved in $10 \mathrm{mM}$ Tris $\cdot \mathrm{HCl}$ buffer to obtain an aqueous solution. The concentration of ouabain in the sample was measured by Beckman spectrophotometer (Beckman Instruments, Inc., Fullerton, Calif.) at $220 \mathrm{~nm}$ and the specific activity was determined initially by assuming that all the ${ }^{3} \mathrm{H}$ activity resided in ouabain. This assumption was checked by measuring the reduction in radioactivity bound to erythrocytes when various amounts of unlabeled ouabain were added to the $\mathrm{Na}-\mathrm{T}-\mathrm{G}$ solution with 0.1 $\mu \mathrm{M}\left[{ }^{3} \mathrm{H}\right]$ ouabain. The specific activity varied from 15.9 to 15.2 $\mathrm{Ci} / \mathrm{mmol} .{ }^{42} \mathrm{~K}$ was obtained as chloride from New England Nuclear. Unlabeled ouabain was obtained from Sigma Chemical Co., St. Louis, Mo. All other solutions were prepared from standard reagent grade chemicals.

\section{Preparation of erythrocyte suspensions}

Fresh heparinized blood was centrifuged within $1 \mathrm{~h}$ of collection. The plasma, buffy coat, and the topmost layer $(=10 \%)$ of the erythrocytes were discarded, and the remaining erythrocytes were resuspended in ice-cold isotonic magnesium chloride, $\mathrm{pH}$ 7.4. During each of the three washes that followed, the supernatant $\mathrm{MgCl}_{2}$ and the topmost layer of erythrocytes were discarded. The precise hematocrit of the washed erythrocyte suspension was determined in triplicate.

\section{Measurement of erythrocyte cation concentrations}

The method used was that of Smith and Samuels (11). The erythrocyte suspension of known hematocrit and volume (usually $0.5 \mathrm{ml}$ ) was lysed, diluted with lithium diluent, and the cation contents determined with a flame photometer (Instrumentation Laboratory Inc., Lexington, Mass.) and calculated as millimoles per liter of erythrocytes. The volume

${ }^{1}$ Abbreviation used in this paper: Na-T-G solution, $130 \mathrm{mM}$ $\mathrm{NaCl}, 10 \mathrm{mM}$ glucose, $10 \mathrm{mM}$ Tris $\cdot \mathrm{HCl}$, and $20 \mathrm{mM}$ sucrose, pH 7.45. fraction of water was calculated from wet and dry weights of cell suspension and specific gravity using the relation published previously (12). Cation concentrations were calculated and expressed as millimoles per liter cell water.

\section{Measurement of $K$ influx}

The method used was that of Sachs and Welt (13). Cells were suspended at 2-4\% hematocrit in Na-T-G solution containing ${ }^{42} \mathrm{~K}$ and $10 \mathrm{mM} \mathrm{KCl}$ for $45 \mathrm{~min}$. The reaction was stopped by adding $10 \mathrm{ml}$ of ice-cold isotonic $\mathrm{MgCl}_{2}$ to the cell suspension. The cells were washed three times at $4^{\circ} \mathrm{C}$ by alternate centrifugation and resuspension in isotonic $\mathrm{MgCl}_{2}$. Radioactivities of cell suspensions and incubation media were determined with a gamma counter (Beckman Instruments, Inc.). Similar experiments were carried out in the presence of $0.5 \mathrm{mM}$ ouabain to measure ouabain-insensitive $\mathrm{K}$ influx. Ouabain-sensitive ${ }^{42} \mathrm{~K}$ influx was calculated as the difference between total and ouabain-insensitive flux. Ouabainsensitive $\mathrm{K}$ influx was measured at various external $\mathrm{K}$ concentrations from 0.25 to $10 \mathrm{mmol} / \mathrm{liter}$ and the concentration of external potassium required for half-maximal pump influx was determined.

\section{Measurement of $\left[{ }^{3} \mathrm{H}\right]$ ouabain binding}

The method used was that of Joiner and Lauf (14). Prewarmed $\left[{ }^{3} \mathrm{H}\right]$ ouabain was added to a $0.2-\mathrm{ml}$ cell suspension in $2 \mathrm{ml}$ of $\mathrm{K}$-free $\mathrm{Na}-\mathrm{T}-\mathrm{G}$ solution at $37^{\circ} \mathrm{C}$ to give a final concentration of $0.1 \mu \mathrm{M}\left[{ }^{3} \mathrm{H}\right]$ ouabain. Studies were performed at least in duplicate and in addition, one study was always performed in the presence of unlabeled ouabain at a concentration of $0.1 \mathrm{mM}$ or more. Maximum ouabain binding was measured after $3 \mathrm{~h}$ of incubation, at which time $0.5-\mathrm{ml}$ aliquots were transferred to a tube containing $9 \mathrm{ml}$ of isotonic ice-cold $\mathrm{MgCl}_{2}, \mathrm{pH} 7.45$, over $2 \mathrm{ml}$ of dibutylphthalate. Upon centrifugation, cells with bound radioactivity settled beneath the organic layer, whereas unbound ouabain remained in the aqueous phase. The aqueous layer was aspirated and traces of $\left[{ }^{3} \mathrm{H}\right]$ ouabain remaining at the side of the tube were removed by carefully pouring fresh $\mathrm{MgCl}_{2}$ up to the brim and aspirating the $\mathrm{MgCl}_{2}$ layer. After aspirating both the organic and aqueous layers, the cells were hemolyzed in icecold $10 \mathrm{mM}$ Tris $\cdot \mathrm{HCl}, \mathrm{pH} 7.45$, and washed twice by centrifugation and resuspension. The cell membranes were solubilized in $0.1 \mathrm{~N} \mathrm{NaOH}$, and the $\beta$-emission counted in a Beckman liquid scintillation counter using Aquasol (New England Nuclear). $\left[{ }^{3} \mathrm{H}\right]$ Ouabain binding sites per cell were calculated by using relations published previously (14). Counts obtained in the presence of $0.5 \mathrm{mM}$ unlabeled ouabain were subtracted for this calculation and never amounted to $>2 \%$ of the total counts.

\section{Kinetics of ouabain binding}

$\left[{ }^{3} \mathrm{H}\right]$ Ouabain binding studies were carried out as described above, and aliquots of cells were withdrawn at various times for determination of $\left[{ }^{3} \mathrm{H}\right]$ ouabain binding. Maximum $\left[{ }^{3} \mathrm{H}\right]$ ouabain binding was always measured on these cells by incubation with $0.1 \mu \mathrm{M}$ ouabain for $3 \mathrm{~h}$.

\section{Correlation between $\left[{ }^{3} \mathrm{H}\right]$ ouabain binding and ${ }^{42} \mathrm{~K}$ influx}

To examine the correlation between $\left[{ }^{3} \mathrm{H}\right]$ ouabain binding 
and ${ }^{42} \mathrm{~K}$ influx, ${ }^{42} \mathrm{~K}$ influx was first measured on cells incubated without $\left[{ }^{3} \mathrm{H}\right]$ ouabain. Cells were then suspended in $\mathrm{K}$ free $\mathrm{Na}-\mathrm{T}-\mathrm{G}$ solution with $\left[{ }^{3} \mathrm{H}\right]$ ouabain as described above. At appropriate times, before maximum ouabain binding occurred, aliquots were withdrawn in quadruplicate. Duplicate samples were layered over $\mathrm{MgCl}_{2}$ and dibutylphthalate and the amount of $\left[{ }^{3} \mathrm{H}\right]$ ouabain bound was determined as above. The other two samples were washed free of supernatant unbound $\left[{ }^{3} \mathrm{H}\right]$ ouabain with ice-cold isotonic $\mathrm{MgCl}_{2}$ (three washes) and suspended in Na-T-G solution with $10 \mathrm{mM} \mathrm{KCl}$ to measure residual ${ }^{42} \mathrm{~K}$ influx remaining after partial occupation of $\mathrm{Na}-\mathrm{K}$ pump sites with ouabain. A few experiments were carried out using $10 \mathrm{nM}\left[{ }^{3} \mathrm{H}\right]$ ouabain. In these experiments, maximum ouabain binding was measured at $3 \mathrm{~h}$ in solutions containing $0.1 \mu \mathrm{M}$ ouabain.

Erythrocyte glutamate oxaloacetate transaminase was measured by the method of Beutler (15). Erythrocyte glucose-6phosphate dehydrogenase was measured by the change in optical density at $340 \mathrm{nM}$ due to NADP reduction using the Sigma test kit. Reticulocytes were stained with a methylene blue stain (Sigma Chemical Co.) and counted with at least 1,000 erythrocytes.

\section{RESULTS}

The clinical data for the steroid-treated group are summarized in Table I.

Intracellular cation concentrations (Fig. 1). Intracellular sodium and potassium concentrations in the normal group were $10.9 \pm 0.23$ and $137.2 \pm 1.2 \mathrm{mmol} /$ liter cell water, respectively (Fig. 1). Intracellular sodium was $7.2 \pm 0.4 \mathrm{mmol} /$ liter cell water in the steroid-treated group, significantly decreased as compared with normals $(P<0.001)$. Intracellular potassium was $149.8 \pm 1.5 \mathrm{mmol} /$ iter cell water, significantly increased as compared with the normal group ( $P$ $<0.001)$. Water content was identical (0.7 liter/liter cells) in both groups.

$K$ influx (Table II). K influx was measured in 10 subjects from the steroid-treated group and 10 subjects from the normal group. The mean intracellular sodium concentrations in these 10 subjects from groups I and II were $11.1 \pm 0.56$ and $7.4 \pm 0.46 \mathrm{mmol} /$ iter cell water, respectively, similar to the averages for the entire group. Several groups of investigators have shown that an increase in intracellular sodium concentration increases, and a decrease in intracellular sodium concentration decreases ouabain-sensitive $K$ influx ( $K$ pump influx) (16-19). However, in spite of a significantly lower intracellular sodium concentration in the steroid-treated group, $\mathrm{K}$ pump influx was the same as that found in the normal group (Table II). The external potassium concentration required for half-maximal $\mathrm{K}$ pump influx was $1.1 \mathrm{mmol} /$ iter in both groups. Ouabain-insensitive $\mathrm{K}$ influx was significantly increased in the steroidtreated group as compared with the normal group $(0.84$ $\mathrm{mmol} / \mathrm{liter}$ cells per h vs. $0.56 \mathrm{mmol} /$ iter cells per $\mathrm{h}$, $P<0.001$ ) (Table II).

Binding of $\left[{ }^{3} \mathrm{H}\right]$ ouabain to intact human erythrocytes. At a ligand concentration of $0.1 \mu \mathrm{M}$, the specific binding of $\left[{ }^{3} \mathrm{H}\right]$ ouabain by erythrocytes from patients receiving glucocorticoids was $15.44 \mathrm{pmol} / \mathrm{ml}$ cells (835 \pm 44 sites/cells), significantly higher than the 8.57 $\mathrm{pmol} / \mathrm{ml}$ cells $(449 \pm 11$ sites/cell) by erythrocytes from normal subjects (Fig. 2).

Ouabain binding was rapid at $0.1 \mu \mathrm{M}\left[{ }^{3} \mathrm{H}\right]$ ouabain,

TABLE I

Clinical Characteristics of Patients from the Steroid-treated Group

\begin{tabular}{|c|c|c|c|c|}
\hline Patient & Age & Sex & Clinical impression & Medications \\
\hline 1 & 56 & M & Membranous nephropathy & Prednisone $40 \mathrm{mg} / \mathrm{d}$, methyldopa, furosemide \\
\hline 2 & 65 & $\mathbf{M}$ & Temporal arteritis & Prednisone $30 \mathrm{mg} / \mathrm{d}$, cimetidine \\
\hline 3 & 28 & M & Acute leukemia & $\begin{array}{l}\text { Prednisone } 100 \mathrm{mg} / \mathrm{d} \text {, isoniazid, ethambutol, nystatin } \\
\text { (local) }\end{array}$ \\
\hline 4 & 29 & M & Sarcoidosis, hypertension, chronic renal failure & $\begin{array}{l}\text { Prednisone } 60 \mathrm{mg} / \mathrm{d} \text {, propranolol, hydralazine, } \\
\text { prazosin }\end{array}$ \\
\hline 5 & 32 & $\mathbf{F}$ & Midline granuloma & Prednisone $60 \mathrm{mg} / \mathrm{d}$, radiation \\
\hline 6 & 62 & $\mathbf{M}$ & Carcinoma of prostate with metastasis & Dexamethasone $8 \mathrm{mg} / \mathrm{d}$, diethylstilbestrol \\
\hline 7 & 56 & $\mathbf{F}$ & Carcinoma of breast & Prednisone $30 \mathrm{mg} / \mathrm{d}$, tamoxifen \\
\hline 8 & 40 & $\mathbf{M}$ & Accelerated hypertension, intracranial bleeding & Dexamethasone $8 \mathrm{mg} / \mathrm{d}$, propranolol, hydralazine \\
\hline 9 & 44 & $\mathbf{M}$ & Membranoproliferative glomerulonephritis & Prednisone $60 \mathrm{mg} / \mathrm{d}$, propranolol \\
\hline 10 & 43 & $\mathbf{M}$ & Goodpasture's syndrome & $\begin{array}{l}\text { Prednisone } 60 \mathrm{mg} / \mathrm{d} \text {, methyldopa, hydralazine, } \\
\text { furosemide }\end{array}$ \\
\hline 11 & 52 & M & Renal transplantation & Prednisone $20 \mathrm{mg} / \mathrm{d}$, azathioprine, isoniazid, prazosin \\
\hline 12 & 82 & $\mathbf{M}$ & Carcinoma of prostate & Prednisone $60 \mathrm{mg} / \mathrm{d}$, methyldopa, furosemide \\
\hline 13 & 43 & M & Hydralazine-induced lupus syndrome & Prednisone $60 \mathrm{mg} / \mathrm{d}$, methyldopa, furosemide \\
\hline 14 & 28 & M & Renal transplantation & Prednisone $40 \mathrm{mg} / \mathrm{d}$, azathioprine \\
\hline 15 & 59 & $\mathbf{M}$ & Rheumatoid arthritis & Prednisone $30 \mathrm{mg} / \mathrm{d}$ \\
\hline 16 & 56 & $\mathbf{M}$ & Extracapillary glomerulonephritis & Prednisone $60 \mathrm{mg} / \mathrm{d}$ \\
\hline 17 & 42 & $\mathbf{M}$ & Membranous nephropathy & Prednisone $60 \mathrm{mg} / \mathrm{d}$, calcium carbonate \\
\hline
\end{tabular}




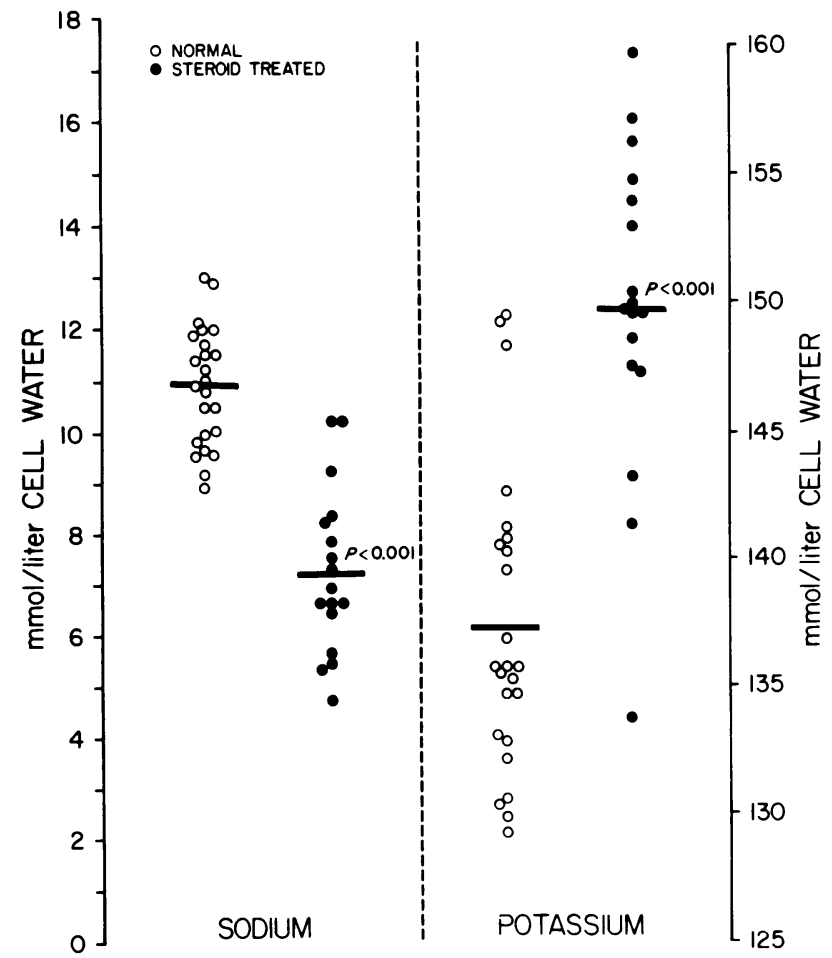

Figure 1 Intracellular sodium and potassium concentration in erythrocytes from a group of 24 normal subjects and 17 steroid-treated subjects.

half-maximal binding was established within $\sim 10 \mathrm{~min}$ in both groups and binding was essentially complete at $60 \mathrm{~min}$ in each and every subject in either group (Fig. 3, top panel).

The interaction of ouabain with its receptor on the Na-K pump could be described by the second order reaction.

$$
\mathrm{Ou}+\mathrm{B} \rightleftharpoons \mathrm{Ou} \cdot \mathrm{B},
$$

where Ou stands for free ouabain, B stands for free ouabain binding sites, $\mathrm{Ou} \cdot \mathrm{B}$ stands for bound ouabain. $\mathrm{Ou} \cdot \mathrm{B}$ is relatively stable, since its dissociation rate is very slow (10). Thus, the velocity of ouabain binding was given by the relation,

$$
d x / d t=k_{b}(a-x)(b-x),
$$

where $a=$ initial concentration of free ouabain, $b$ $=$ initial concentration of free ouabain binding sites, $x=$ concentration of bound ouabain, and $t=$ time in minutes. The association rate constant $k_{b}$ was given by integrating and rearranging (2).

$$
k_{b}=\frac{1}{(a-b) t} \text { In } \frac{b(a-x)}{a(b-x)} .
$$

A plot of the value

$$
\frac{1}{(a-b)} \operatorname{In} \frac{b(a-x)}{a(b-x)}
$$

plotted against time was linear in both groups. The line for the normal group was $y=-0.01+0.07 x, \mathrm{r}^{2}=0.94$ and that for the steroid-treated group was $y=+0.01$ $+0.07 x, r^{2}=0.89$. The two lines were not significantly different. The association rate constant $k_{b}$ given by the slope of the plots was $0.07 \times 10^{7} / \mathrm{mol}$ per min in both groups, indicating that the affinity of ouabain for its receptor on the Na-K pump was unchanged in the erythrocytes from the glucocorticoid-treated group in spite of the increase in the total number of $\mathrm{Na}-\mathrm{K}$ pump sites in the latter group.

Thus, the principal feature of the $\left[{ }^{3} \mathrm{H}\right]$ ouabain binding studies was a marked increase in the total number of ouabain binding sites in the erythrocytes from the glucocorticoid-treated group; in other respects the receptor for ouabain was qualitatively identical to the one found in normal subjects.

Correlation of $\left[{ }^{3} \mathrm{H}\right]$ ouabain binding and ${ }^{42} \mathrm{~K}$ influx. To determine whether the increase in $\left[{ }^{3} \mathrm{H}\right]$ ouabain binding in the glucocorticoid-treated group was a reflection of a specific increase in $\mathrm{Na}-\mathrm{K}$ pump sites or an increase in ouabain binding at nonpump sites, further studies were performed. Aliquots of cells were removed from a bath containing $\left[{ }^{3} \mathrm{H}\right]$ ouabain at various times before maximum binding occurred. After washing off supernatant $\left[{ }^{3} \mathrm{H}\right]$ ouabain as described earlier, these cells were evaluated for residual $\mathrm{K}$ influx. These partially inhibited $K$ pump influxes were measured in order to correlate ouabain binding to $\mathrm{K}$ pump inhibi-

\begin{tabular}{|c|c|c|c|}
\hline & Normal & Steroid-treated & $P$ value \\
\hline $\begin{array}{l}\text { Ouabain sensitive } \\
\mathrm{K} \text { influx (mmol/liter } \\
\text { cells/h) (External } \\
\mathrm{K}=10 \mathrm{mmol} / \mathrm{liter})\end{array}$ & $\begin{array}{c}1.23 \pm 0.08 \\
(n=10)\end{array}$ & $\begin{array}{c}1.17 \pm 0.07 \\
(n=10)\end{array}$ & NS* \\
\hline $\begin{array}{l}\text { Ouabain insensitive } \\
\mathrm{K} \text { influx (mmol/liter } \\
\text { cells } / \mathrm{h} \text { ) (External } \\
\mathrm{K}=10 \mathrm{mmol} / \mathrm{liter})\end{array}$ & $\begin{array}{c}0.56 \pm 0.03 \\
(n=10)\end{array}$ & $\begin{array}{c}0.84 \pm 0.06 \\
(n=10)\end{array}$ & 0.001 \\
\hline $\mathrm{K}_{0.5}(\mathrm{mmol} /$ liter $)$ & $\begin{array}{c}1.1 \\
(n=5)\end{array}$ & $\begin{array}{c}1.1 \\
(n=3)\end{array}$ & NS* \\
\hline $\begin{array}{l}\text { Intracellular } \\
\text { Sodium (mmol/liter } \\
\text { cell water) }\end{array}$ & $\begin{array}{c}11.1 \\
(n=10)\end{array}$ & $\begin{array}{c}7.4 \\
(n=10)\end{array}$ & 0.001 \\
\hline
\end{tabular}

TABLE II

Characteristics of $K$ Influx in the Normal and Steroid-treated Group

* Not significant. 


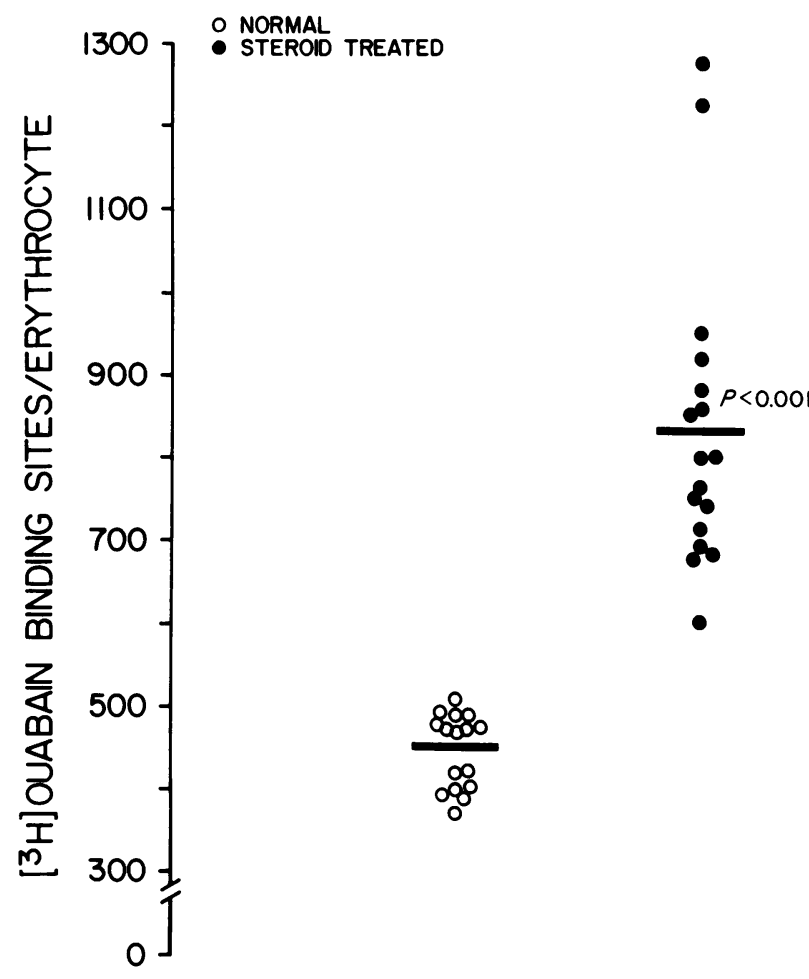

FIgURE $2\left[{ }^{3} \mathrm{H}\right]$ ouabain binding sites per cell in a group of 16 normal subjects and 17 subjects from the steroid-treated group. Erythrocytes were incubated in potassium-free Na-T-G solution with $0.1 \mu \mathrm{M}\left[{ }^{3} \mathrm{H}\right]$ ouabain for $3 \mathrm{~h}$. Binding was measured as described in Methods. Counts obtained in the presence of unlabeled ouabain $(0.5 \mathrm{mM})$ were subtracted to obtain specific maximum ouabain binding, which is shown in the figure.

tion as a consequence of the binding of ouabain. ${ }^{42} \mathrm{~K}$ pump influx decreased as ouabain binding increased (Figs. 3 and 4). The full complement of receptor site occupancy was required for complete inhibition of $\mathrm{K}$ influx (Figs. 3 and 4). No more $\left[{ }^{3} \mathrm{H}\right]$ ouabain binding could be achieved in either group after $100 \%$ inhibition of $\mathrm{K}$ pump influx, suggesting the absence of nonspecific ouabain binding (Fig. 3). The pump influx remaining after partial occupancy of $\mathrm{Na}-\mathrm{K}$ pump sites by bound $\left[{ }^{3} \mathrm{H}\right]$ ouabain (residual $\mathrm{K}$ pump influx, Fig. 3) was subtracted from the total pump influx (uninhibited) present before addition of $\left[{ }^{3} \mathrm{H}\right]$ ouabain at time zero (Fig. 3) to obtain the degree of inhibition of $\mathrm{K}$ pump influx. Fig. 4 plots the percent inhibition of $\mathrm{K}$ pump influx against the fractional occupancy of $\left[{ }^{3} \mathrm{H}\right]-$ ouabain binding sites. The plots were linear in both groups. The linearity of plot in normal subjects confirmed earlier observations of the one-to-one relationship between ouabain molecules bound and $\mathrm{Na}-\mathrm{K}$ pump sites (10). The linearity of plot in the glucocorticoid-treated group provided evidence for the specificity of $\left[{ }^{3} \mathrm{H}\right]$ ouabain binding in representing additional $\mathrm{Na}-\mathrm{K}$ pump sites.
Serial measurements after steroid administration. Fig. 5 shows serial measurements of intracellular sodium, potassium, and $\left[{ }^{3} \mathrm{H}\right]$ ouabain binding sites in a patient after administration of a $60 \mathrm{mg} / \mathrm{d}$ dose of prednisone. A rise in $\left[{ }^{3} \mathrm{H}\right]$ ouabain binding sites was observed after $4 \mathrm{wk}$ and reached maximum values after 8-12 wk. A fall in the intracellular sodium concentration was observed 2-3 wk after the increase in ouabain binding sites. Both maximum $\left[{ }^{3} \mathrm{H}\right]$ ouabain binding sites and intracellular sodium concentration reached a plateau after $12 \mathrm{wk}$ in spite of continued administration of prednisone in the same dose.
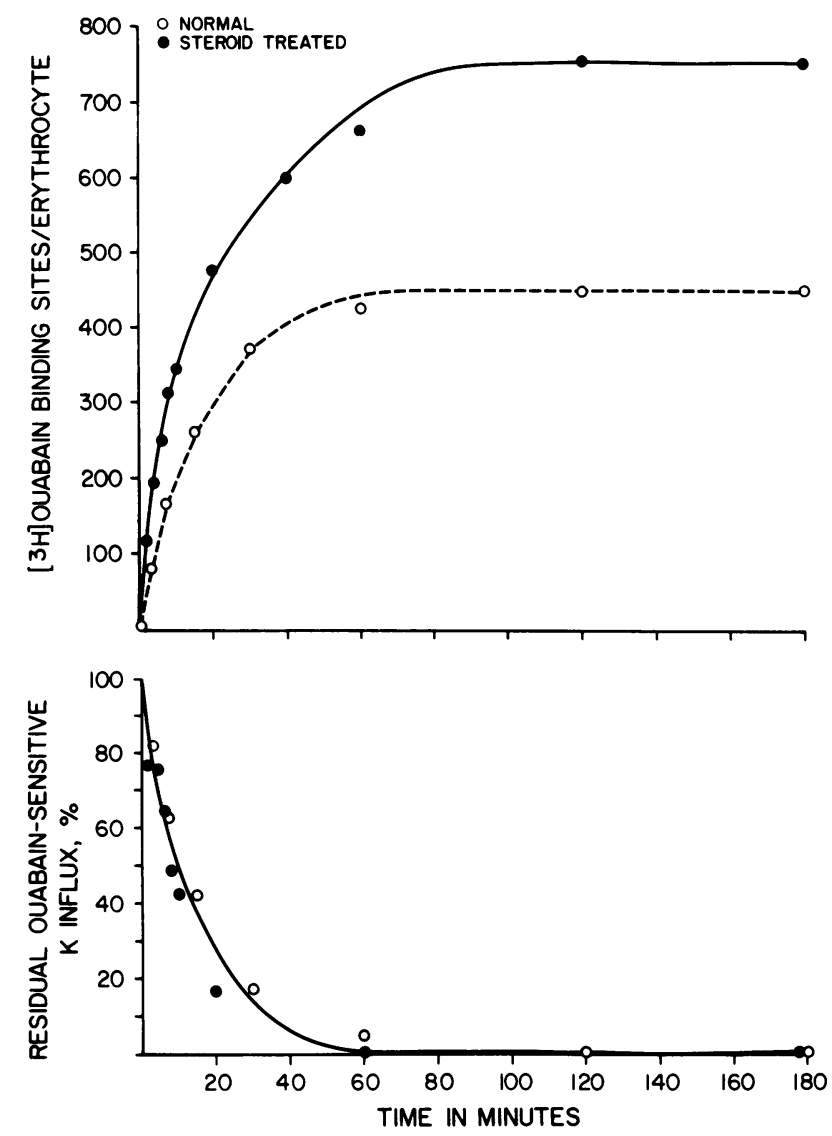

FIGURE 3 Time-course of ouabain binding and ouabainsensitive potassium influx ( $K$ pump influx) in erythrocytes from normal $(O)$ and steroid-treated group $(O)$. The experiment was representative of four studies in the normal group and seven studies in the steroid-treated group. Erythrocytes were incubated in a potassium free $\mathrm{Na}-\mathrm{T}-\mathrm{G}$ solution and $\left[{ }^{3} \mathrm{H}\right]-$ ouabain at $0.1 \mu \mathrm{M}$ was added at time zero. At the indicated times, samples were taken for ouabain binding (upper panel) and potassium influx (lower panel). Potassium influx was measured in Na-T-G solution containing $10 \mathrm{mmol}$ potassium/liter. The percent residual ouabain-sensitive $K$ influx was derived as $\frac{\text { K pump influx, sample }}{\text { K pump influx, uninhibited (time zero) }} \times 100$ 


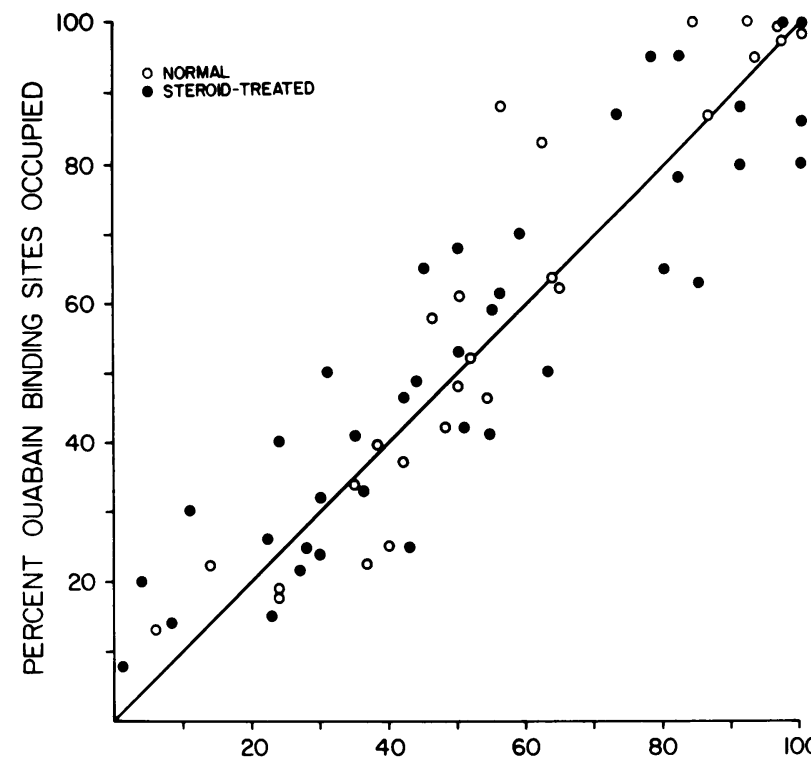

PERCENT INHIBITION OF OUABAIN-SENSITIVE $K$ INFLUX

FIGURE 4 Correlation between ouabain binding and inhibition of ouabain-sensitive $K$ influx ( $K$ pump influx) in erythrocytes from a group of four normal subjects and seven subjects from the steroid-treated group. Percent inhibition of $\mathrm{K}$ pump influx was calculated as:

K pump influx, uninhibited-K pump influx, sample (residual K pump influx) $\times 100$. $\mathrm{K}$ pump influx uninhibited

In some experiments, $10 \mathrm{nM}$ ouabain was used to achieve a low percent occupation of ouabain binding sites with accuracy. The line of identity is shown. The line for the normal group was $y=-1.11+1.06 x, \mathrm{r}^{2}=0.90$ and that for the steroid-treated group was $y=4.90+0.88 x, \mathrm{r}^{2}=0.88$. These two lines were not statistically different.

Paired studies. In five additional patients, ouabain binding, erythrocyte sodium and potassium concentrations were measured during glucocorticoid treatment and compared with pretreatment values. Ouabain binding increased $(845 \pm 94$ vs. $405 \pm 17$ sites/cells, $P$ $<0.01)$, erythrocyte sodium decreased $(7.4 \pm 1.0 \mathrm{vs} .11 .4$ $\pm 1.0 \mathrm{mmol} /$ /iter cell water, $P<0.05$ ), and erythrocyte potassium increased $(150.7 \pm 3.2$ vs. $138.3 \pm 1.0 \mathrm{mmol} /$ liter cell water, $P<0.05)$ as compared with pretreatment values. These results suggest that the observed alterations in the $\mathrm{Na}-\mathrm{K}$ pump in the glucocorticoid group were a result of the administration of glucocorticoids and not due to the disease state.

In vitro incubation of normal erythrocytes with methylprednisolone. Both intact cells and erythrocyte ghosts were incubated in Na-T-G solution containing methylprednisolone sodium succinate $0.1 \mathrm{mM}$. Intracellular cation concentrations and ${ }^{3} \mathrm{H}$ binding sites were measured before and up to $24 \mathrm{~h}$ after the incubation and compared to control erythrocytes incubated without the drug. There was no difference in $\left[{ }^{3} \mathrm{H}\right]-$ ouabain binding sites, net sodium, or potassium flux in the two groups (data not shown).

Morphological and enzymatic characteristics of erythrocytes. To estimate the mean erythrocyte age, we measured several morphological and enzymatic characteristics of the erythrocytes from the two groups. There was no significant difference in the density, mean corpuscular hemoglobin, or the mean corpuscular hemoglobin concentrations in the two groups. Mean corpuscular volume was $89.1 \pm 1.2 \mathrm{fl}$ in the steroidtreated group as compared with $87.5 \pm 0.2 \mathrm{fl}$ in the normal group $(P<0.001)$. Reticulocyte count was 0.94 $\pm 0.16 \%$ in whole blood from the steroid-treated group as compared with $0.84 \pm 0.13 \%$ in the subjects from normal groups. Erythrocyte glucose-6-phosphate dehydrogenase was $7.67 \pm 1.13 \mathrm{U} / \mathrm{g}$ hemoglobin in a group of six patients from the steroid-treated group, not significantly different from the normal value of $7.64 \pm 1.24 \mathrm{U} / \mathrm{g}$ hemoglobin. Erythrocyte glutamate oxaloacetate transaminase level in these patients was $5.29 \pm 1.16 \mathrm{U} / \mathrm{g}$ hemoglobin as compared with 4.80 $\pm 1.31 \mathrm{U} / \mathrm{g}$ hemoglobin in the normal group (NS). Ouabain binding in these patients was $865 \pm 79$ sites/cell. There was no correlation between ouabain binding and percent reticulocytes, erythrocyte glucose-6-phosphate dehydrogenase levels or erythrocyte glutamate oxaloacetate transaminase.
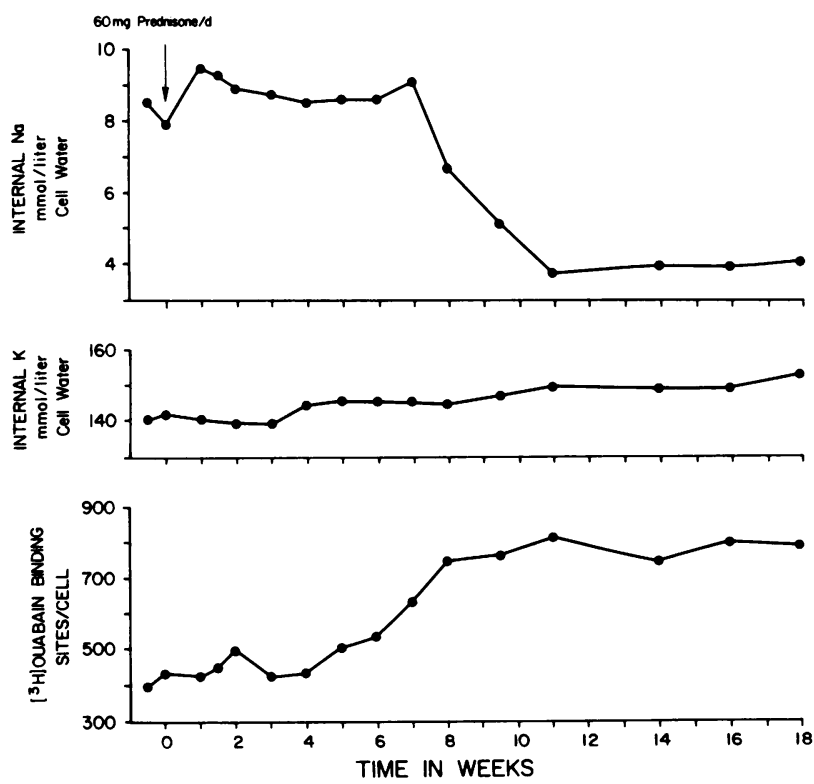

FIgURE 5 Serial measurements of intracellular sodium concentration (upper panel), potassium concentration (middle panel), and ouabain binding sites per cell (lower panel) in a subject receiving $60 \mathrm{mg}$ prednisone/d. Prednisone was started at time zero and continued throughout the 8-wk course in the same dose. 


\section{DISCUSSION}

Clinical conditions associated with glucocorticoid excess are accompanied by positive sodium balance, hypertension, and hypokalemia. Conversely, deficiency of glucocorticoids, as in Addison's disease or adrenalectomy, is accompanied by sodium loss, hypotension, and hyperkalemia (20). Extensive and elegant investigations have been carried out to define various cellular and subcellular mechanisms of action of glucocorticoid hormones (21). However, relatively little information is available on the effect of glucocorticoids on the Na-K pump in human subjects. In view of the importance of this active pump mechanism in modulating renal and extrarenal transport of potassium and sodium in health and various disease states, we undertook a detailed examination of the effects of exogenous glucocorticoids on the Na-K pump of the human erythrocytes.

An alteration in the activity of the Na-K pump is often reflected by a change in the intracellular concentration of sodium. Thus, in the uremic state and in subjects taking digoxin, a decrease in the activity of the $\mathrm{Na}-\mathrm{K}$ pump is reflected by an increase in the intracellular sodium concentration $(22,23)$. Conversely, our initial findings of decreased intracellular sodium concentration and increased intracellular potassium concentration in erythrocytes from the steroid-treated group (Fig. 1) strongly suggest that the activity of the Na-K pump was enhanced. A less attractive possibility is that the reciprocal changes in the intracellular cation concentrations were the result of a simultaneous decrease in the passive permeability of the cell membranes to both sodium and potassium without any significant alteration in Na-K pump activity.

Several groups of investigators have shown that changes in the intracellular concentration of sodium have a direct and almost linear correlation with $\mathrm{K}$ pump influx (16-19). Thus, a decrease in intracellular sodium, such as that observed in the steroid-treated group, would be expected to lower $\mathrm{K}$ pump influx as compared with normals. However, $K$ pump influx was unchanged in the steroid-treated group despite lower intracellular sodium (Table II), suggesting that $K$ pump influx would be higher in the steroid-treated group when measured under conditions where the internal ionic milieu were comparable in the two groups. The lack of diminution in K pump influx in spite of lower intracellular sodium concentration provides additional evidence of enhanced activity of the Na-K pump in erythrocytes from the steroid-treated group. The finding of an increase in ouabain-insensitive $K$ influx is in keeping with the concept of pump-leak interdependence and is somewhat analogous to other disease states such as hereditary spherocytosis, hereditary stomatocytosis, and in $\mathrm{Rh}$ null cells in which similar, concomitant changes in the pump activity and passive fluxes were observed (24-26).

To determine whether increased activity of the Na-K pump in erythrocytes from the steroid-treated group represented an increased number of $\mathrm{Na}-\mathrm{K}$ pump sites or increased ion turnover per pump site, $\left[{ }^{3} \mathrm{H}\right]$ ouabain binding was measured. The number of ouabain binding sites was significantly higher in the cells from the steroid-treated group. Several lines of evidence suggest that the values for $\left[{ }^{3} \mathrm{H}\right]$ ouabain binding reported here represent maximum values for ouabain binding. The concentration of ouabain used was higher than that used by other investigators (27). Concentrations of ouabain $>0.1 \mu \mathrm{M}$ failed to give higher values for $\left[{ }^{3} \mathrm{H}\right]$ ouabain binding. At a concentration of $0.1 \mu \mathrm{M}$, ouabain binding reached a plateau and did not change after $1 \mathrm{~h}$ (Fig. 3). It was also noteworthy that complete inhibition of $\mathrm{K}$ pump influx was observed with the amount of ${ }^{3} \mathrm{H}$ ]ouabain binding reported (Figs. 3 and 4 ). Increased $\left[{ }^{3} \mathrm{H}\right.$ ]ouabain binding in the glucocorticoid group did not represent an increase in the affinity of ouabain for its receptor on the Na-K pump, since we have shown that the association rate constants for ouabain binding were similar in the glucocorticoid and normal group.

The possibility that increased $\left[{ }^{3} \mathrm{H}\right]$ ouabain binding in the glucocorticoid group may be due to a greater proportion of reticulocyte and younger cells in circulation must also be considered, since reticulocyte-rich erythrocyte populations and younger cells separated by density gradients have been shown to have an increase in $\left[{ }^{3} \mathrm{H}\right]$ ouabain binding $(28,29)$. However, the reticulocyte count in our steroid-treated patients was not elevated. Younger cells and reticulocytes have higher activities of erythrocyte glucose-6-phosphate dehydrogenase and glutamate oxaloacetate transaminase $(30,31)$, whereas the activities of these enzymes were not significantly higher in erythrocytes from steroid-treated patients. There was no correlation between ouabain binding and erythrocyte enzyme levels, indicating that the higher ouabain binding obtained in the steroid-treated group was not due to a younger cell population. Furthermore, younger cells have significantly lower density, higher water content, and lower mean hemoglobin concentration $(28,32-34)$. Density, water content, and mean hemoglobin concentration were almost identical in the cells from normal and steroid-treated groups. Thus, the observations reported here cannot be attributed to a difference in the age of cells in the two groups, but must be due to other direct effects of glucocorticosteroids on the erythrocytes. Since there was no difference in the morphology of the cells in the two groups and mean corpuscular volume was only sightly higher in the steroidtreated group (89.1 $\mathrm{fl}$ as compared with $87.5 \mathrm{fl}$ in the normal group), it is safe to assume that differences in surface area could not account for the increase in $\left[{ }^{3} \mathrm{H}\right]-$ ouabain binding. Thus, the increased $\left[{ }^{3} \mathrm{H}\right]$ ouabain binding in erythrocytes from the steroid-treated group represented an increased density of $\mathrm{Na}-\mathrm{K}$ pump sites 
rather than a major increase in the surface area of the cells.

Several rigorous tests for assessing the specificity of $\left[{ }^{3} \mathrm{H}\right]$ ouabain binding to Na-K pump sites of normal erythrocytes have been described by previous workers $(8,10)$. Using these methods, we attempted to ascertain whether increased $\left[{ }^{3} \mathrm{H}\right]$ ouabain binding in the steroid-treated groups represented increased number of Na-K pump sites. There was a linear correlation between the percent occupancy of ouabain binding sites and the percent inhibition of ouabain-sensitive $\mathrm{K}$ influx, so that all of the ouabain-sensitive $\mathrm{K}$ influx was inhibited when all of the ouabain binding sites were occupied in erythrocytes from both groups (Figs. 3 and 4). No further ouabain binding was observed after complete inhibition of K pump (Fig. 3). The maximum number of binding sites at $3 \mathrm{~h}$ was in all cases almost identical to the number obtained from extrapolation of the line correlating binding with inhibition of ouabain-sensitive $\mathrm{K}$ influx (Fig. 4). At two different ouabain concentrations $(0.1 \mu \mathrm{M}$ and $10 \mathrm{~nm})$ a given fractional occupancy of ouabain binding sites was associated with the similar fractional inhibition of $\mathbf{K}$ pump influx, even though it took considerably longer to occupy the same number of pump sites at lower (10 $\mathrm{nM}$ ) ouabain concentration (Fig. 4). Thus, the correlation between ouabain binding and the inhibition of $K$ pump influx in both groups was independent of both the time of incubation and the concentration of ouabain used. These findings are similar to those reported earlier by other workers for ouabain binding in normal subjects (10) and strongly suggest that ouabain binding was specific for the Na-K pump sites in erythrocytes from the steroid-treated group as well as normals. In addition, the linearity of the plot (Fig. 4) suggests that all the pump sites in the glucocorticoid group were functionally homogenous with respect to $K$ pump influx.

Using the equation for second order reactions, we calculated the association rate constant $\left(k_{b}\right)$ for the association of ouabain to its binding site in normal subjects and patients from the steroid-treated group. Our finding of similar association rate for the steroid-treated group taken together with the finding of similar $\mathrm{K}_{0.5}$ for $\mathrm{K}$ influx with respect to external potassium suggests that the ouabain binding and the $\mathrm{Na}-\mathrm{K}$ pump were qualitatively similar in the two groups and that no conformational change was detectable in the $\mathrm{Na}-\mathrm{K}$ pump in the steroid group using the methods described.

It is currently believed that glucocorticoids act at the transcriptional or post-transcriptional stage to derepress the genome, allowing RNA translation and protein synthesis to proceed in the nucleus (20). Since the circulating, mature erythrocyte is enucleate and does not synthesize protein and RNA, it is most likely that the observed alterations in the Na-K pump occurred during the course of erythropoiesis and were primarily directed at the nucleated precursor cells. The observation of a long lag period between the initiation of glucocorticoid administration and the attainment of peak values of $\left[{ }^{3} \mathrm{H}\right]$ ouabain binding sites is in agreement with this proposal (Fig. 5). In addition, the alternative but less likely possibility that glucocorticoids act on the mature erythrocyte is not supported by our failure to induce changes in $\left[{ }^{3} \mathrm{H}\right]$ ouabain binding or net sodium or potassium flux in erythrocytes and ghosts during in vitro incubation in a bath containing methylprednisolone.

Thus, our results indicate that administration of glucocorticoids in pharmacologic doses, given for a wide variety of clinical disorders, consistently results in an increase in the surface density of $\mathrm{Na}-\mathrm{K}$ pumps on human erythrocytes, an increase in intracellular potassium, and a decrease in intracellular sodium concentration. Our working hypothesis for the observed alterations in Na-K pump invokes an increase in the number of $\mathrm{Na}-\mathrm{K}$ pump sites as the primary event, with the consequent increase in pump activity resulting in active sodium extrusion up to a point where the lowering of intracellular sodium decreased sodium efflux and potassium influx back to the original steady-state values, albeit in the face of lower intracellular sodium concentration. The finding that increase in $\left[{ }^{3} \mathrm{H}\right]$ ouabain binding preceded changes in intracellular electrolytes (Fig. 5) supports this construct. These findings are consistent with earlier observations of an increase in Na-K ATPase in the rat kidney following the administration of glucocorticoids (4) and extend these observations in human subjects. The present data do not allow us to exclude the possibility that these observations may be explained by occupancy of mineralocorticoid receptors by pharmacological doses of glucocorticoids (35). In this context, it is of interest to note that both dexamethasone and aldosterone have been shown to restore Na-K ATPase in adrenalectomized rats but the doses of aldosterone required to restore $\mathrm{Na}$ K ATPase levels in earlier experiments were supermaximal with respect to mineralocorticoid action, leading to the inference that the increase in $\mathrm{Na}-\mathrm{K}$ ATPase was the result of occupancy of glucocorticoid receptors by aldosterone $(4,36)$.

Cole and Maletz (37) reported decreased erythrocyte sodium and increased Na-K ATPase in renal transplant recipients, and observed that the changes were the obverse of those reported in uremia. In light of the findings presented here, it appears likely that the findings described in transplant recipients were, in large part, due to the administration of prednisone in those patients. Conventionally, glucocorticoids are thought to have little or no influence on the transport of sodium or potassium in the kidney or the gut. Our finding of consistent and major alterations of the Na-K pump in human erythrocytes during glucocorticoid administration suggests the need to further define a 
more precise role of glucocorticoids in modulating electrolyte transport in man.

\section{ACKNOWLEDGMENTS}

We thank Dr. Eugene Roth, Jr., for measurements of erythrocyte glucose-6-phosphate dehydrogenase and Dr. Neville Colman for measurements of erythrocyte glutamate oxaloacetate transaminase. We thank Bernice Middleton for technical assistance and Evelyn Shapiro for secretarial assistance.

This work was supported in part by the General Medical Research Service of the Veterans Administration and a grant from The Kidney Foundation of New York.

\section{REFERENCES}

1. Glynn, I. M., and S. J. D. Karlish. 1975. The sodium pump. Annu. Rev. Physiol. 37: 13-55.

2. Dunham, P. B., and J. F. Hoffman. 1978. Na and K transport in red blood cells. In Physiology of Membrane Disorders. T. Andreoli, J. F. Hoffman, and D. D. Fanestil, editors. Plenum Publishing Corp., New York. 255-272.

3. Cavieries, J. D. 1977. The sodium pump in human red cells. In Membrane Transport in Red Cells. J. E. Ellory and V. L. Lew, editors. Academic Press Inc., New York. $1-37$.

4. Hendler, E. O., J. Toretti, L. Kupor, and F. H. Epstein. 1972. Effects of adrenalectomy and hormone replacement on $\mathrm{Na}^{+}-\mathrm{K}^{+}$-ATPase in renal tissue. Am. J. Physiol. 222: 754-760.

5. Fisher, K. A., L. G. Welt, and J. P. Hayslett. 1975. Dissociation of Na-K-ATPase specific activity and net reabsorption of sodium. Am. J. Physiol. 228: 1745-1749.

6. Charney, A. N., M. O. Kinsey, L. Myers, R. Gianella, and R. E. Gotts. 1975. $\mathrm{Na}^{+}-\mathrm{K}^{+}$-activated adenosine triphosphatase and intestinal electrolyte transport. J. Clin. Invest. 56: 653-660.

7. Gall, G., P. Usher, J. C. Melby, and R. Klein. 1971. Effects of aldosterone and cortisol on human erythrocyte $\mathrm{Na}$ efflux. J. Clin. Endocrinol. Metab. 32: 555-561.

8. Hoffman, J. F. 1969. The interaction between tritiated ouabain and the Na-K pump in red blood cells. J. Gen. Physiol. 54: 343s-350s.

9. Baker, P. F., and J. S. Willis. 1972. Binding of cardiac glycoside ouabain to intact cells. J. Physiol. (Lond.). 224: 441-462.

10. Joiner, C. H., and P. K. Lauf. 1978. The correlation between ouabain binding and potassium pump inhibition in human and sheep erythrocytes. J. Physiol. (Lond.). 283: 151-175.

11. Smith, E. K. M., and P. D. Samuels. 1970. Abnormalities in the sodium pump of erythrocytes from patients with hyperthyroidism. Clin. Sci. 38: 49-61.

12. Cook, J. S. 1967. Nonsolvent water in human erythrocytes. J. Gen. Physiol. 50: 1311-1325.

13. Sachs, J. R., and L. G. Welt. 1967. The concentration dependence of active potassium transport in the human red blood cell. J. Clin. Invest. 46: 65-76.

14. Joiner, C. H., and P. K. Lauf. 1975. The effects of anti-L on ouabain binding to sheep erythrocytes. J. Memb. Biol. 21: 99-112.

15. Beutler, E. 1971. Red Cell Metabolism. A Manual of Biochemical Methods. Grune \& Stratton, New York. 2nd edition. 75-76.

16. Sachs, J. R. 1970. Sodium movement in the human red blood cell. J. Gen. Physiol. 56: 322-341.

17. Garay, R. P., and P. J. Garrahan. 1974. A kinetic study of the Na pump in red cells. Its relevance to the mechanisms of active transport. Ann. N. Y. Acad. Sci. 242: 445-458.

18. Knight, A., and L. G. Welt. 1974. Intracellular potassium as a determinant of the sodium potassium pump rate.J. Gen. Physiol. 63: 351-373.

19. Joiner, C. H., and P. K. Lauf. 1978. Modulation of ouabain binding and potassium pump fluxes by cellular sodium and potassium in human and sheep erythrocytes. $J$ Physiol. (Lond.). 283: 177-196.

20. Liddle, G. W. 1974. Adrenal cortex. In Textbook of Endocrinology. R. Williams, editor. W. B. Saunders Company, Philadelphia. 5th edition. 233-284.

21. Feldman, D., G. W. Funder, and I. S. Edelman. 1972. Subcellular mechanisms in the action of adrenal steroids. Am. J. Med. 53: 545-560.

22. Welt, L. G., J. R. Sachs, and T. J. McManus. 1964. An ion transport defect in erythrocytes from uremic patients. Trans. Assoc. Am. Physicians. 77: 169-181.

23. Loes, M. W., S. Singh, J. E. Lock, and B. L. Mirkin. 1978. Relation between plasma and red cell electrolyte concentrations and digoxin levels in children. N. Engl.J.Med. 299: 501-504.

24. Wiley, J. S. 1972. Co-ordinated increase in sodium leak and sodium pump in hereditary spherocytosis. $\mathrm{Br} . \mathrm{J}$. Haematol. 22: 529-542.

25. Wiley, J. S., J. C. Ellory, M. A. Shulman, C. C. Shaler, and R. A. Cooper. 1975. Characteristics of the membrane defect in hereditary stomatocytosis syndrome. Blood. 46: $337-386$

26. Lauf, P. K., and C. H. Joiner. 1976. Cation transport and $\left[{ }^{3} \mathrm{H}\right]$ ouabain binding in human red cells lacking the rhesus antigen (Rh null cells) Biophys. J. 16: 169a.

27. Erdmann, E., and W. Hasse, 1975. Quantitative aspects of ouabain binding to human erythrocyte and cardiac membranes. J. Physiol. (Lond.). 251: 671-682.

28. Joiner, C. H., and P. K. Lauf. 1978. Ouabain binding and potassium transport in young and old populations of human red cells. Membr. Biochem. 1: 187-201.

29. Wiley, J. S., and C. C. Shaller. 1977. Selective loss of calcium permeability on maturation of reticulocytes. $J$. Clin. Invest. 59: 1113-1119.

30. Chapman, R. G., and L. Schaumburg. 1967. Glycolysis and glycolytic enzyme activity of aging red cells in man. Br.J. Hematol. 13: 665-678.

31. Beutler, E. 1972. Energy metabolism, energy function and maintenance of erythrocytes. In Hematology. W. J Williams, E. Beutler, A. J. Erslev, and R. W. Rundles, editors. McGraw-Hill, Inc., New York. 132-144.

32. Bernstein, R. E. 1959. Alterations in metabolic energetics and cation transport during aging of red cells. J. Clin. Invest. 38: 1572-1586.

33. Drankerd, T. A. J. 1958. Aging of red cells. J. Physiol. (Lond.). 143: 325-331.

34. Hanahan, D. 1978. Chemical composition of membranes. In Membrane Transport in Biology. G. Giebisch, D. C. Tosteson, and H. H. Ussing, editors. Springer-Verlag, New York, Inc., New York. 1: 208-214.

35. Cake, M. H., and G. Litwack. 1975. The glucocorticoid receptor. In Biochemical Actions of Hormones. G. Litwack, editor. Academic Press, Inc., New York. 3: 317-390.

36. Jorgensen, P. L. 1969. Regulation of the (Na-K) activated ATP hydrolysing enzyme system in rat kidney. II. The effect of aldosterone on the activity in kidneys of adrenalectomized rats. Biochim. Biophys. Acta. 192: 326-334.

37. Cole, C. H., and R. Maletz. 1975. Changes in erythrocyte membrane ouabain sensitive adenosine triphosphatase after renal transplantation. Clin Sci. Mol. Med. 47: 239-245. 